\title{
The record of climate and uplift in the palaeo-Ganga plain: A way to decipher the interactions between climate and tectonics
}

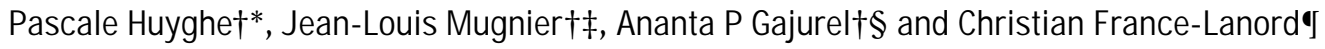 \\ † LGCA Grenoble University, FRANCE \\ ‡ LGCA CNRS, FRANCE \\ $\S$ Tri-Chandra College, Tribuvan University, Kathmandu, NEPAL \\ I CRPG Nancy, FRANCE \\ *To whom correspondence should be addressed.E-mail: huyghe@ujf-grenoble.fr
}

\begin{abstract}
Foreland basin sediments provide a record of the tectonic and climatic processes that control the morphologic evolution of mountain belts, through their sedimentological, geochemical and geophysical characteristics. The Siwalik continental molasses were deposited in the Tertiary Himalayan foreland basin. These sediments represent the record of more than $15 \mathrm{Ma}$ of Himalayan denudation. They consist of fluvial deposits strongly influenced by the Neogene tectonics of the mountain belt. Also the climatic changes that affected the area are recorded in them. A multidisciplinary study has been conducted in the Siwaliks of Nepal in order to decipher the interactions between climate and tectonics.
\end{abstract}

Analysis of the tectonic-sediment relationships to estimate shortening velocity

From growth structures and reworked Middle Siwalik blocks, the timing of the Siwalik Thrusts has been specified: it is found to be 1.8-2.4 Ma for the initiation of the Main Frontal Thrust (MFT) and 2.4-3 Ma for the Main Dun Thrust (MDT). From balanced cross-sections through the Siwalik belt it has been shown that the shortening rate is greater than $17 \mathrm{~mm} / \mathrm{yr}$. A comparison between global positioning system (GPS) studies, shortening rate inferred from the uplift of Holocene terraces above the thrust and balanced cross-sections through the Lesser Himalaya suggests that the shortening rate is constant over the different periods of time and close to $19 \mathrm{~mm} / \mathrm{yr}$ (Mugnier et al. 2003).

In summary, the convergence rate in Himalaya may be considered as constant since $\sim 11 \mathrm{Ma}$ and possibly $20 \mathrm{Ma}$.

Analysis of the geometry of the foreland basin as a marker of the Himalayan thrust wedge evolution

Geometry of foreland basins is primarily controlled by subsidence and provides a data set fairly independent from climate evolution. We analysed major erosion surfaces and migration of the sedimentary sequences between 20 and $0 \mathrm{Ma}$ from seismic reflection profiles and logs of the Ganga basin and field data on the Siwalik belt. Three main periods may be distinguished as given below:

0-2 Ma: No major migration is detected for both the southward edge of the post-Siwalik sequences and the location of the most external Himalayan thrust. As the shortening rate is constant, the width of the belt must have narrowed. The altitude remained nearly constant as it is affected by strong erosion $(\sim 2.5$ $\mathrm{mm}$, from Galy and France-Lanord 2001) that balances the solid advection.

2-13 Ma: Siwalik sequences (s.s.) migrated southwards with speed varying from 10 to $16 \mathrm{~mm} / \mathrm{yr}$ close to the shortening rate (Lyon-Caen and Molnar, 1985). This suggests that the whole geometry of the Himalaya-Ganga basin system has been translated above the Indian Plate and the altitude of the belt has remained fairly constant.

13-20 Ma: no southward migration of the Ganga basin may be observed but a major erosion affected the pre-13 Ma deposits. Back-stripping of magneto-stratigraphic sections permitted to reconstruct the evolution of subsidence and calculate the curvature of the Indian lithosphere (Lyon-Caen et Molnar 1983). From 17 to 13 Ma erosion affected temporarily large area of the foreland basin, and a northward migration of the peripheric bulge is inferred.

We propose that a continental slab separated from the Indian lithosphere prior to $13 \mathrm{Ma}$. It would have induced an uplift of the Himalayan belt over a $>100 \mathrm{~km}$ width.

In summary there is no large scale relief changes since 13 $\mathrm{Ma}$, but a major uplift occurred in Himalaya between 20-13 Ma.

Analysis of the filling of the Tertiary foreland basin

Facies analysis, geochemistry and clay mineralogy studies have been realized to detect and characterize the events recorded by the Siwalik molasses. Our analysis mainly focuses on sections which have been accurately dated by magnetostratigraphy (Gautam and Roesler 1999): Karnali section, Surai section and Tinau section, respectively located in Western, Middle West and Central Nepal.

\section{Oxygen and carbon isotopes of gastropods}

Mollusca fossils (10 to $2 \mathrm{Ma}$ ) were collected from clayey and sandy lithologies representing channel and floodplain sediments of the paleo-Ganga plain. The isotopic data of fossil shells show:

i) a sudden increase in $\delta^{13} \mathrm{C}$ values at $5 \mathrm{Ma}$ with values varying between $-12 \%$ and $-6 \%$ o prior to $5 \mathrm{Ma}$ to values varying between $-4 \%$ ond $+2 \%$. This increase in $\delta^{13} \mathrm{C}$ values corresponds to the change of carbon isotopic composition of rivers induced by the expansion of C4-plants. This expansion is also well documented by pedogenic carbonates or by teeth of mammals in the Siwaliks (Quade et al. 1995).

ii) the high variability of oxygen isotopic data with values ranging from -16 to $-2 \%$ o PDB. The upper limit $(\sim-2 \%$ o) is present since $10 \mathrm{Ma}$ suggesting confined environment with possible evaporation of water for biogenic carbonate accretion. The lower limit of oxygen isotopic data varies with time. Prior to $5 \mathrm{Ma}$, one third of the values range between -11 and $-15 \%$ while between 5 and $1 \mathrm{Ma}$, a unique sample among 25 has a $\delta^{18} \mathrm{O}$ value of $12 \%$. These data therefore imply that prior to $5 \mathrm{Ma}$, the river waters in the Gangetic plain could reach very low $\delta^{18} \mathrm{O}$ values or that temperatures were much higher than during $5 \mathrm{Ma}$ to $1 \mathrm{Ma}$ period. A temperature control is not realistic; therefore these 
results suggest that prior to $5 \mathrm{Ma}$, rivers waters could have reached much lower isotopic composition than the present-day range for the Ganga (-6 and $-10 \%$ o). Such conditions could derive from higher elevation of the Himalayan watershed relative to present.

\section{Sedimentary facies and clay mineralogy}

i) Facies analysis has been used to characterize the major changes of the Siwalik fluvial system.

ii) $\varepsilon_{N d}(0)$ was used as a source indicator as the sharp contrast in $\varepsilon_{\mathrm{Nd}}(0)$ between the juxtaposed crustal terranes in the Himalayas provides the possibility to identify sediment provenance and detect large-scale tectonic evolution of the belt (Huyghe et al. 2001).

iii) When source rocks are constant, clay mineralogy is considered as a weathering indicator.

Combining these three data sets, it is shown that the major changes evidenced in the Western Siwalik of Nepal from a meandering to a braided system and from a sandy braided system to debris-flow-dominated braided system were linked to the uplift and/or migration of the major Himalayan thrust system (constant weathering indicators, similar fluvial changes not synchronous from one section to the other one). The fluvial change recorded at $6.4 \pm 0.5 \mathrm{Ma}$ from a deep sandy braided river system to a shallow sandy river system would rather have a climatic origin as shown by the constant source marker and the quasi-simultaneity of its occurrence over more than $(600 \times 100)$ $\mathrm{km}^{2}$. As the sediment accumulation rate has not significantly changed (Gautam and Rosler 1999), this change of fluvial style could be due to an increase of the bed-load of the river in relation with a change of water discharge that would either diminish or be controlled by seasonality.

\section{Conclusions}

Both the characteristics of the deposits and the geometry of the Siwalik molassic sequences show that this part of the Himalayan foreland basin mainly follows a classic steady state evolution controlled by the continuous convergence in the Himalayan belt.
Nonetheless, events of different origins occurred and are detected in the foreland basin:

-A lithospheric event before $13 \mathrm{Ma}$

-Crustal-scale tectonic events

○ Initiation of motion along the Lesser Himalaya Thrust System around $11 \mathrm{Ma}$;

- Initiation of motion along the thrust system of the Siwalik domain (MFT, MDT and inner Siwalik thrusts)

-A major climatic event superimposed after $7 \mathrm{Ma}$, as recorded by different markers.

From this timing inferred from the Siwalik record, it is suggested that the huge relief of Himalaya has enhanced on its southern flank the effect of the south-east Asian monsoon strengthening from $7 \mathrm{Ma}$. Nonetheless no direct feed-back has been found between tectonic evolution of the Himalayan belt and climate at a larger scale than the Himalaya; the relief of Himalaya predates by several Myrs the main south-east Asian monsoon strengthening, and there is no direct correlation between tectonic events and climatic events.

\section{References}

Galy A and C France-Lanord. 2001. Higher erosion rates in the Himalaya: Geochemical constraints on riverine fluxes. Geology 29: 23-26

Gautam P and W Roesler. 1999. Depositional Chronology and fabric of Siwalik group sediments in Central Nepal from magnetostratigraphy and Magnetic anisotropy, in Le Fort, P., and B.N. Upreti, eds., Geology of the Nepal Himalayas: recent advances: Journal of Asian Earth Sciences, Special issue 17:659-82

Huyghe P, A Galy, J-L Mugnier and C France-Lanord. 2001. Propagation of the thrust system and erosion in the Lesser Himalaya: Geochemical and sedimentological evidence. Geology 29: 1007-10

Lyon-Caen H and P Molnar. 1985. Gravity anomalies, flexure of the Indian plate, and the structure, support and evolution of the Himalaya and Ganga basin, Tectonics 4: 513-38

Mugnier JL, P Huyghe, P Leturmy and Jouanne F. 2003. Episodicity and rates of thrust sheet motion in Himalaya (Western Nepal), in "Thrust Tectonics and Hydrocarbon Systems", Mc Clay, eds, AAPG Mem. 82: 124. SPI Publisher Services, 11147 Air Park road, Suite 4. Ashland, VA 23005

Quade J, JML Cater, TP Ojha, J Adam and TM Harrison. 1995. Late Miocene environmental change in Nepal and the northern Indian subcontinent: Stable isotopic evidence from paleosols. GSA Bulletin 107 (12): 1381-97 